\title{
PERAN KEPALA SEKOLAH DAN GURU DALAM MENCIPTAKAN SEKOLAH YANG MENYENANGKAN DI SMA NEGERI 3 TAKALAR
}

\author{
Nurwindah $^{1}$, Supriadi Torro ${ }^{2}$ \\ 1,2Program Studi Pendidikan Sosiologi, Fakultas Ilmu Sosial, Universitas Negeri Makassar \\ Nurwindah@gmail.com ${ }^{1}$, supriaditorro@unm.ac.id ${ }^{2}$
}

\begin{abstract}
ABSTRAK
Penelitian ini bertujuan untuk mengetahui; 1) Peran kepala sekolah dan guru dalam menciptakan sekolah yang menyenangkan di SMA Negeri 3 Takalar dan 2) Kendala yang dihadapi dalam menciptakan sekolah yang menyenangkan di SMA Negeri 3 Takalar. Jenis penelitian ini adalah penelitian deskriptif kualitatif dengan jumlah informan sebanyak 11 orang yang ditentukan dengan Teknik pengumpulan data dengan cara observasi, wawancara, dokumentasi, teknik pengabsahan data menggunakan trigulasi sumber. Hasil penelitian ini menunjukkan bahwa Peran Kepala Sekolah dan guru dalam menciptakan sekolah yang menyenangkan di SMA Negeri 3 Takalar adalah; 1) Peran kepala sekolah dalam menciptakan sekolah yang menyenangkan di SMA Negeri 3 Takalar yaitu dengan menjadi pengelola aktivitas PBM di sekolah (manajer), mengelola kurikulum yang diterapkan (administrator), mengamati dan mengevaluasi proses pembelajaran melalui kunjungan kelas (supervisor), memimpin semua aktivitas di sekolah (leader), pembaharu dalam proses pembelajaran di sekolah (innovator), dan mendorong tenaga pendidikan di sekolah untuk bekerja sesuai dengan fungsinya (motivator). Adapun peran guru yaitu sebagai pengajar di dalam kelas, menjadi sosok panutan dalam sikap dan kepribadian (pendidik) dan sebagai pengasah keterampilan dari hasil proses pembelajaran (melatih). 2) Kendala yang dihadapi kepala sekolah dalam menciptakan sekolah yang menyenangkan di SMA Negeri 3 Takalar yaitu komunikasi yang kurang terjalin baik dengan guru dan fungsi pengawasan yang berjalan kurang maksimal. Adapun kendala yang dihadapi oleh guru yaitu masih minimnya fasilitas yang dapat menunjang proses belajar mengajar di kelas serta masih kurangnya kompetensi guru dalam melaksanakan PBM.
\end{abstract}

Kata kunci: Sekolah menyenangkan, kepala sekolah, Guru

\begin{abstract}
This study aims to determine; 1) The role of school principals and teachers in creating pleasant schools in SMA 3 Takalar and 2) Obstacles faced in creating fun schools in SMA Negeri 3 Takalar. This type of research is a qualitative descriptive study with 11 informants as determined by data collection techniques by observation, interviews, documentation, data validation techniques using source trigulation. The results of this study indicate that the role of headmasters and teachers in creating fun schools in SMA Negeri 3 Takalar is; 1) The role of the principal in creating a fun school in SMA 3 Takalar is to be a manager of PBM activities in the school (manager), manage the applied curriculum (administrator), observe and evaluate the learning process through class visits (supervisors), lead all activities in the school (leader), a reformer in the learning process in the school (innovator), and encourage education personnel in the school to work in accordance with its function (motivator). The teacher's role is as a teacher in the classroom, being a role model in attitudes and personalities (educators) and as a skill sharpener from the results of the learning process (training). 2) The obstacle faced by school principals in creating fun schools in SMA Negeri 3 Takalar is the lack of good communication with the teacher and the oversight function that runs less. The obstacles faced by teachers are the lack of facilities that can support the teaching and learning process in the classroom and the lack of teacher competence in implementing PBM
\end{abstract}

Keywords: Fun School, Headmaster, Teacher

\section{PENDAHULUAN}

Pendidikan merupakan salah satu modal dasar untuk menciptakan SDM yang unggul. Dunia pendidikan yang utama adalah sekolah. Sekolah merupakan salah satu lembaga alternatif pelayanan pendidikan. Sekolah sebagai suatu lembaga tentunya memiliki visi, misi, tujuan dan fungsi. Untuk mengemban misi, mewujudkan visi, 


\section{Jurnal Sosialisasi \\ Jurnal Hasil Pemikiran, Penelitian, dan Pengembangan \\ Keilmuan Sosiologi Pendidikan \\ Vol 7, SNomor 2, Jufi 2020}

mencapai tujuan, dan menjalankan fungsinya sekolah memerlukan tenaga profesional, tata kerja organisasi dan sumber-sumber yang mendukung baik finansial maupun non finansial. (Nuraeni \& Ishak, 2017)

Dalam menjalankan perannya itu, maka kepala sekolah perlu melaksanakan peranan administrasi pendidik yang pada dasarnya meliputi perencanaan, pelaksanaan, pengawasan dan kepemimpinan, kedisiplinan guru adalah sikap penuh kerelaan dalam mematuhi semua aturan dan norma yang ada dalam menjalankan tugasnya sebagai bentuk tanggung jawabnya terhadap pendidikan anak didiknya (Sulastri, 2014). Sebagai pemimpin pendidikan kepala sekolah mempunyai peran yang sangat besar dalam mengembangkan semangat kerja dan kerjasama yang harmonis, minat terhadap perkembangan dunia pendidikan, perkembangan kualitas propesional guru-guru yang dipimpinnya, serta kualitas siswa atau sekolah secara umum banyak ditentukan oleh kualitas kepala sekolah.

Senang berarti perasaan puas, lega, tidak kecewa ataupun susah. Dengan demikian, sekolah menyenangkan dapat diartikan sebagai sekolah yang mampu membuat semua warga sekolah senang, puas, lega, akan situasi sekolah. Sekolah menyenangkan tidak hanya tertuju pada upaya bagaimana membuat peserta didik betah ke sekolah, namun juga menyenangkan bagi guru, tenaga kependidikan, bahkan orangtua peserta didik.

Pada prinsipnya konsep sekolah menyenangkan merupakan perpaduan dari konsep sekolah sehat, amat, dan ramah anak. Mengapa demikian dikatatakan seperti itu, karena ketika prinsip-prinsip sekolah sehat, aman, dan ramah anak terpenuhi, maka secara otomatis sekolah tersebut menjadi menyenangkan bagi peserta didik, guru, tenaga pendidikan, orangtua dan warga sekitar sekolah

Kepala sekolah dalam menjalankan kepemimpinannya dituntut untuk memahami tugas dan tanggung jawab yang diembannya, memahami karakteristik bawahannya dan memahami fenomena yang terjadi di lingkungannya, sehingga mampu meningkatkan serangkain hubungan kerja dengan bawahan dalam upaya meningkatkan kualitas pendidikan. keadaan tersebut tidak lepas dari fungsi kepala sekolah yang sangat mulia demi masa depan suatu generasi dan masa depan bangsa.

Sekolah menyenangkan menjadi tempat terbaik bagi setiap warga sekolah untuk mengekspresikan bakat, minat, dan prestasi yang dimilikinya, bukan menjadi tempat yang mengasingkan (Ratna \& Torro, 2019). Mereka pun menjadi bagian dari sekolah itu karena sekolah memberi ruang bagi perkembangan warga sekolah, terutama peserta didik, sehingga mereka tidak terasing dari sekolah tersebut. Kepala sekolah di SMA Negeri 3 Takalar dalam masa kepemimpinannya itu memiliki jiwa pemimpin yang baik bagi guru dan peserta didiknya, sehingga guru dan tenaga kependidikan itu merasa senang dan puas dalam masa jabatannya selama menjabat sebagai kepala sekolah. Tujuan penelitian ini untuk mengurakain bagaiama peran kepala sekolah dan guru dalam menciptakan sekolah meneyengkan dana pa kendala yang dihadapi dalam menciptakan sekolah yang menyenangkan di Sekolah Menengah Atas Negeri 3 Takalar.

\section{METODE PENELITIAN}

Penelitian ini menggunakan pendekatan deskriptif dengan jenis penelitian kualitatif. Pendekatan deskriptif yaitu menggambarkan, memaparkan dan mengungkapkan hasil penelitian peran kepala sekolah dan guru dalam menciptakan sekolah menyenangkan di SMA Negeri 3 Takalar. Sehingga penelitian dapat tergambar secara jelas. Pendekatan deskriptif adalah suatu proses penelitian dan pemahaman yang berdasarkan pada metodologi yang menyelidiki suatu fenomena sosial dan masalah manusia (Suyanto, 2015). Jenis penelitian kualitatif sebagai prosedur penelitian yang menghasilkan data deskriptif 
berupa kata-kata atau lisan dari orang-orang dan perilaku yang dapat diamati. Bogdan mendefinisikan "jenis penelitian kualitatif sebagai prosedur penelitian yang menhasilkan deskripsi berupa kata-kata tertulis atau lisan dari orang-orang atau perilaku yang diamati (Anggito \& Setiawan, 2018).

\section{HASIL PENELITIAN DAN PEMBAHASAN}

\section{Peran Kepala Sekolah dan Guru Menciptakan Sekolah Yang Menyenangkan}

Dari hasil penelitian menunjukkan bahwa peran kepala sekolah lebih besar dibandingkan guru. Kepala sekolah adalah struktur tertinggi dalam ruang lingkup sekolah. Oleh karena itu, peranan kepala sekolah lebih besar dibandingkan guru biasa. Kepala sekolah harus memposisikan dirinya sebagai manajer, administrator, supervisor, leader, inovator, dan motivator. Salah satu peranan penting kepala sekolah adalah menjadi manajer. Dari hasil wawancara menunjukkan kepala sekolah mampu melakukan perencanaan, pengorganisasian, kepemimpinan dan mengatur sekolah dalam rangka mencapai visi dan misi yang ditetapkan. Adanya peran kepala sekolah yang mampu memanajemen sekolah dengan baik dan akan menghasilkan proses belajar mengajar yang menyenangkan. Sehingga sekolah menjadi tempat yang menyenangkan sebagai sarana pendidikan.

Dalam rangka melakukan peran dan fungsinya sebagai manajer, kepala sekolah perlu memiliki strategi yang tepat untuk memberdayakan tenaga pendidik dan kependidikan melalui persaingan yang membuahkan kerja sama (cooperation), memberikan kesempatan kepada tenaga kependidikan untuk meningkatkan profesinya, dan mendorong keterlibatan seluruh tenaga pendidik dan kependidikan dalam berbagai kegiatan yang menunjang program sekolah (Murniati, 2008).

Sesuai kriteria penilaian kinerja kepala sekolah, maka kepala sekolah perlu memiliki kemampuan dalam melaksanakan tugas kepemimpinannya dengan baik yang diwujudkan dalam kemampuan menyusun program, organisasi personalia, memberdayakan tenaga kependidikan, dan menberdayakan sumber daya sekolah secara optimal dalam rangka melakukan peran dan fungsinya sebagai manajer, kepala sekolah harus memiliki strategi yang tepat untuk memberdayakan tenaga kependidikan melalui kerjasama yang kooparatif, memberikan kesempatan kepada tenaga kependidikan untuk meningkatkan profesinya dan mendorong keterlibatan seluruh tenaga kependidikan dalam berbagai kegiatan yang menunjang program sekolah (Fitrah, 2017).

Peranan penting kepala sekolah lainnya adalah menjadi administrator. Manajemen dan administrasi adalah satu paket yang tidak dapat dipisahkan karena keduanya saling berkesinambungan. Manajemen yang baik harus di tunjang dengan administrasi yang kuat. Peran kepala sekolah sebagai administrator sangat urgen dalam proses pembelajaran. Ada beberapa hal terkait administrasi yang ditemukan dari proses wawancara yakni masalah kurikulum, sarana prasarana, dan keuangan. Hal tersebut membuat siswa puas sehingga proses belajar mengajar di sekolah terasa menyenangkan (Wahyudi \& Azizah, 2016). Pengelolaan kurikulum yang baik dan mampu menciptakan proses pembelajaran sesuai dengan kehidupan dilingkungan peserta didik akan sangat berpengaruh terhadap proses pembelajaran. Sarana dan prasarana penunjang akan mempengaruhi peningkatan belajar mengajar sehingga terciptanya kreativitas pada pendidik dan pengajar. Dari kesemuanya faktor keuangan adalah penunjang semua aktifitas tersebut. 
Adapun dalam hal administrator kepala sekolah sangat menentukan baik dalam hal perencanaan dan pengesahan segala macam bentuk administrasi sekolah. Sedangkan dalam hal supervisor kepala sekolah sangat menentukan segala arah kebijakan yang berkaitan dengan supervisi di sekolah. Kepala sekolah mempunyai peran sebagai administrator dan supervisor pada dasarnya memberikan layanan profesional untuk meningkatkan mutu pendidikan melalui peningkatan kinerja guru. Kondisi pelaksanaan pembinaan oleh kepala sekolah yaitu kegiatan yang dilakukan untuk mengawasi pelaksanaan administrasi sekolah, tugas rutin guru-guru, ketertiban, disiplin dan keberhasilan sekolah. Kegiatan pembinaan kepala sekolah seperti di atas tentunya akan berpengaruh terhadap peningkatan kinerja guru. Keberhasilan sekolah tidak terlepas dari tugas dan tanggung jawab serta peranan kepala sekolah.

Kepala sekolah sebagai Administrator bertanggung jawab terhadap kelancaran pelaksanaan pendidikan dan pengajaran di sekolahnya. Hal tersebut mencakup seluruh kegiatan sekolah, seperti; proses belajar-mengajar, kepeserta didikan, personalia, sarana prasarana, ketatausahaan dan keuangan serta mengatur hubungan sekolah dengan masyarakat. Selain itu juga, kepala sekolah bertanggung jawab terhadap keadaan lingkungan sekolahnya (Chatib, 2009).

Peran kepala sekolah sebagai supervisor. Proses pembelajaran yang sesuai dengan perangkat pembelajaran adalah tujuan utama dari guru. Untuk mengetahui sejauh mana guru mampu melaksanakan pembelajaran, secara berkala kepala sekolah perlu melaksanakan kegiatan supervisi, yang dapat dilakukan melalui kegiatan kunjungan kelas untuk mengamati proses pembelajaran secara langsung, terutama dalam pemilihan dan penggunaan metode, media yang digunakan dan keterlibatan peserta didik dalam proses pembelajaran (Mulyasa, 2004). Dari hasil supervisi ini, dapat diketahui kelemahan sekaligus keunggulan guru dalam melaksanakan pembelajaran, tingkat penguasaan kompetensi guru yang bersangkutan, selanjutnya diupayakan solusi, pembinaan dan tindak lanjut tertentu sehingga guru dapat memperbaiki kekurangan yang ada sekaligus mempertahankan keunggulannya dalam melaksanakan pembelajaran.

Supervisi dalam pendidikan telah lama dikenal namun tidak semua orang dalam dunia pendidikan mengerti apa hakekat supervisi itu sendiri. Supervisi disamakan dengan pekerjaan mengawasi, supervisi lebih banyak mengawasi daripada berbagai ide pengalaman. Sebagai supervisor, Kepala Sekolah mensupervisi pekerjaan yang dilakukan oleh tenaga kependidikan. Supervisi merupakan suatu proses yang dirancang secara khusus untuk membantu para guru dan supervisor mempelajari tugas sehari-hari di sekolah, agar dapat menggunakan pengetahuan dan kemampuannya untuk memberikan layanan yang lebih baik pada orang tua peserta didik dan sekolah, serta berupaya menjadikan sekolah sebagai komunitas belajar yang lebih efektif. Jika supervisi dilaksanakan oleh kepala sekolah, maka ia harus mampu melakukan berbagai pengawasan dan pengendalian untuk meningkatkan kinerja tenaga kependidikan. Pengawasan dan pengendalian ini merupakan kontrol agar kegiatan pendidikan di sekolah terarah pada tujuan yang telah ditetapkan.

Pengawasan dan pengendalian juga merupakan tindakan preventif untuk mencegah agar tenaga kependidikan tidak melakukan penyimpangan dan lebih cermat melaksanakan pekerjaannya. Pengawasan dan pengendalian yang dilakukan kepala sekolah terhadap tenaga kependidikan khususnya guru, disebut supervisi klinis, yang bertujuan untuk meningkatkan kemampuan profesional guru dan meningkatkan kualitas pembelajaran melalui pembelajaran efektif. Kepala sekolah sebagai supervisor perlu memperhatikan 
prinsip-prinsip: (1) hubungan konsultatif, kolegial dan bukan hirarkis; (2) dilaksanakan secara demokratis; (3) berpusat pada tenaga kependidikan; (4) dilakukan berdasarkan kebutuhan tenaga kependidikan; dan (5) merupakan bantuan professional (Istiqlali, 2017). Adanya peningkatan mengajar yang dirasakan oleh siswa SMA Negeri 3 Takalar, tak lain dari hasil supervisi kepala sekolah kepada guru untuk menciptakan sekolah yang menyenangkan.

Peran kepala sekolah sebagai leader/pemimpin. Sekolah merupakan salah satu bentuk organisasi pendidikan. Kepala sekolah merupakan pemimpin pendidikan di sekolah. Jika pengertian kepemimpinan tersebut diterapkan dalam organisasi pendidikan, maka kepemimpinan pendidikan bisa diartikan sebagai suatu usaha untuk menggerakkan orang-orang yang ada dalam organisasi pendidikan untuk mencapai tujuan pendidikan. Hal ini sesuai dengan pendapat Nawawi yang mengemukakan bahwa kepemimpinan pendidikan adalah proses mempengaruhi, menggerakkan, memberikan motivasi, dan mengarahkan orang-orang yang ada dalam organisasi pendidikan untuk mencapai tujuan pendidikan.

Peran-peran kepala sekolah yang harus di mainkan dewasa ini adalah kepala sekolah sebagai educator (pendidik), yakni harus mampu memberi bimbingan kepada seluruh warga sekolah, memberi dorongan kepada semua tenaga kependidikan, menciptakan iklim yang kondusif, juga harus mampu menyelenggarakan model pembelajaran yang menarik, program akselerasi bagi siswa yang memiliki kecerdasan di atas normal dan program remedial untuk anak yang mengalami kesulitan dalam pembelajaran.

Peran selanjutnya adalah Motivator. Dalam proses pembelajaran rasa jenuh pasti akan hadir. Oleh karena itu untuk menciptakan Susana semangat kepala sekolah dan guru harus menjadi motivator buat siswanya. Dari hasil penelitian, siswa merasa senang dan semangat belajar. Guru pun memberikan pengajaran yang baik pula. Ini menunjukkan peran kepala sekolah sebagai motivator di sekolah berjalan dengan baik begitupun dengan guru ke siswa. Motivator yang adalah keinginan yang mendorong seseorang untuk berbuat sesuatu (Nurhikmahyanti, 2013). Kepala sekolah harus memiliki kemampuan untuk memotivasi seluruh sumber daya manusia yang ada di sekolah dalam rangka pencapaian tujuan pendidikan di sekolah. Motivasi merupakan faktor yang dominan yang menentukan keefektifan kerja.

Peran guru dan kepala sekolah dalam menciptakan sekolah yang menyenangkan tidaklah mudah ketika melaksanakannya di lapangan. Perlu kedisiplinan yang tinggi agar semua berjalan dengan baik. Penelitian tersebut sama halnya dengan penelitian yang dilakukan mengenai peran kepemimpinan kepala sekolah terhadap pembinaan guru di SMA Negeri I Galesong Selatan Kabupaten Takalar". Hasil penelitian ini menunjukkan bahwa; 1) Peran kepemimpinan kepala sekolah terhadap guru-guru SMA Negeri 1 Galesong Selatan Kabupaten Takalar adalah; Pembuatan silabus dan rencana pelaksanaan pembelajaran (RPP); peningkatan kemampuan membuka pelajaran; peningkatan sikap atatu perilaku dalam proses pembelajaran; peningkatan kemampuan menguasai materi pembelajaran; penyajian materi pembelajaran sesuai dengan tujuan dan indikator pembelajaran; peningkatan keterampilan guru untuk menanggapi dan merespon pertanyaan siswa; peningkatan kemampuan guru menggunakan media pembelajaran; pembuatan alat evaluasi pembelajaran; peningkatan kemampuan menutup pembelajaran; dan peningkatan kemampuan guru dalam memberikan tindak lanjut, berupa mengayaan atau pendalaman 
materi. 2) Kendala-kendala yang di hadapi oleh kepala sekolah dalam melakukan pembinaan terhadap guru di SMA Negeri 1 Galesong Selatan Kabupaten Takalar, yaitu : guru kurang disiplin dalam menjalankan tugas dan kewajibannya, guru kurang kreatif dalam mengembangkan diri, sarana dan prasarana kurang tersedian sebagai pendukung pembinaan, dan (d) motivasi guru untuk berprestasi sangat kurang.

Faktor terpenting dari kedua penelitian tersebut adalah komunikasi yang baik antara guru dan kepala sekolah sebagai bentuk kerjasama untuk menciptakan sekolah yang menyenangkan. Peranan guru dan kepemimpinan seorang kepala sekolah akan menciptakan siswa yang senag berada di sekolah. Peran guru telah meningkat dari sebagai pengajar menjadi sebagai direktur pengarah belajar. Sebagai direktur belajar, tugas dan tanggung jawab guru menjadi lebih meningkat yang kedalamnya termasuk fungsi-fungsi guru sebgai perencanaan pengajaran, pengelola pengajaran, penilai hasil belajar, sebagai motivator belajar, dan sebagai pembimbing peranan guru itu akan makin tampak, kalau di kaitkan dengan kebijaksanaan dan program pembangunan dalam pendidikan dewasa ini, yaitu berkenaan dengan peningkatan mutu lulusan atau hasil pendidikan itu sendiri.

\section{Kendala-Kendala Dalam Menciptakan Sekolah Yang Menyenangkan}

Dari hasil wawancara menunjukkan bahwa tanggap informan tentang kendara yang dialami oleh siswa adalah masih adanya siswa yang belum mampu menjalankan sekolah yang menyenangkan. Dari hasil wawancara menunjukkan bahwa tanggap informan tentang peran kepala sekolah sudah sesuai dengan harapan dan apa yang selama ini sudah dilakukan selama menjabat sebagai kepala sekolah. Hal ini sama dengan teori dimana salah satu peranan penting kepala sekolah dan guru adalah bagaimana menjadi motivator.

Sekolah sebagai wahana pembelajaran tak diragukan berperan besar dalam pengembangan karakter siswa. Sekolah telah mengantar anak-anak dan remaja dalam menyelesaikan tugas perkembangannya hingga memasuki masa dewasa dengan baik. Di lembaga ini otak, hati, dan badan anak di ditumbuhkembangkan agar lebih cerdas, peka dan sehat (Helmi, 2017). Dengan kecerdasan otak, kepekaan hati, dan kesehatan fisik diaharapkan dapat mejadi modal kemandirian di masa yang akan datang. Fenomena ketuntasan belajar yang rendah tersebut dapat disebabkan oleh beban kurikulum yang terlalu berat. Sistem pendidikan sekolah seperti itu dapat berpengaruh negatif terhadap usaha membangun karakter. Sebab, dalam waktu yang panjang sebagian "terposisikan inferior" rasa percaya dirinya. Rasa tidak mampu yang berkepanjangan tersebut akan membentuk pribadi yang kurang percaya diri, dan menimbulkan stress berkepanjangan. Pada usia remaja biasanya keadaan ini akan mendorong remaja berperilaku negatif, seperti senang tawuran, terlibat kriminalitas, putus sekolah, dan menurunnya mutu lulusan. Karena itu kritik-kritik yang ditujukan pada pendidikan persekolahan (Fauzi, n.d.)

Hasil penelitian yang dilakukan mengenai peranan kepala sekolah dalam meningkakan kedisiplinan guru Di SMP Negeri 1 Majauleng Kabupaten Wajo bahwa kepala sekolah berperan dalam meningkatkan kedisiplinan guru di SMP Negeri 1 Majauleng Kabupaten Wajo. Hal ini dapat dilihat dari beberapa indikator yaitu kepala sekolah sebagai pemimpin yang telah mampu merumuskan dan menentukan tujuan sekolah yang akan dicapai, Kepala sekolah sebagai manajer memiliki peran yang kuat dalam mengkoordinasikan, menggerakkan dan menyelarisasikan semua sumber daya pendidikan yang tersedia, kepala sekolah sebagai supervisor mampu mengadakan pengawasan kepada para guru dengan kunjungan kelas untuk mengamati guru yang sedan mengajar, kepala 
sekolah sebagai mottivator yaitu deng memberikan penghargaan kepada guru yang berprestasi

Sekolah sebagai wahana pembelajaran tak diragukan berperan besar dalam pengembangan karakter siswa (Wiyono, 2012), (Awaru, 2017). Sekolah telah mengantar anak-anak dan remaja dalam menyelesaikan tugas perkembangannya hingga memasuki masa dewasa dengan baik. Di lembaga ini otak, hati, dan badan anak ditumbuh kembangkan agar lebih cerdas, peka dan sehat. Kecerdasan otak, kepekaan hati, dan kesehatan fisik diaharapkan dapat mejadi modal kemandirian dimasa yang akan datang.

\section{PENUTUP}

Berdasarkan penelitian tentang peran kepala sekolah dan guru dalam menciptakan sekolah yang menyenangkan di SMA Negeri 3 Takalar maka dapat ditarik kesimpulan sebagai berikut: Peran kepala sekolah dalam menciptakan sekolah yang menyenangkan di SMA Negeri 3 Takalar yaitu dengan menjadi pengelola aktivitas PBM di sekolah (manajer), mengelola kurikulum yang diterapkan (administrator), mengamati dan mengevaluasi proses pembelajaran melalui kunjungan kelas (supervisor), memimpin semua aktivitas di sekolah (leader), pembaharu dalam proses pembelajaran di sekolah (innovator), dan mendorong tenaga pendidikan di sekolah untuk bekerja sesuai dengan fungsinya (motivator). Adapun peran guru yaitu sebagai pengajar di dalam kelas, menjadi sosok panutan dalam sikap dan kepribadian (pendidik) dan sebagai pengasah keterampilan dari hasil proses pembelajaran (melatih). Kendala yang dihadapi kepala sekolah dalam menciptakan sekolah yang menyenangkan di SMA Negeri 3 Takalar yaitu komunikasi yang kurang terjalin baik dengan guru dan fungsi pengawasan yang berjalan kurang maksimal. Adapun kendala yang dihadapi oleh guru yaitu masih minimnya fasilitas yang dapat menunjang proses belajar mengajar di kelas serta masih kurangnya kompetensi guru dalam melaksanakan PBM.

\section{DAFTAR PUSTAKA}

Anggito, A., \& Setiawan, J. (2018). Metodologi penelitian kualitatif. CV Jejak (Jejak Publisher).

Awaru, A. O. T. (2017). Membangun Karakter Bangsa Melalui Pendidikan Berbasis Multikultural Di Sekolah. Prosiding Seminar Nasional Himpunan Sarjana Ilmu-Ilmu Sosial, 2, 221-230.

Chatib, M. (2009). Sekolahnya manusia: sekolah berbasis multiple intelligences di Indonesia. Kaifa.

Fauzi, A. (n.d.). Strategi pengembangan madrasah model. Menatap wajah, 109.

Fitrah, M. (2017). Peran kepala sekolah dalam meningkatkan mutu pendidikan. Jurnal Penjaminan Mutu, 3(1), 31-42.

Helmi, M. (2017). Peran lembaga pendidikan nonformal terhadap perkembangan perilaku anak di Kelurahan Dasan Geres Kec. Gerung Kab. Lombok Barat Tahun Pelajaran 2016/2017. UIN Mataram.

Istiqlali, A. T. (2017). Supervisi akademik kepala madrasah tsanawiyah: penelitian di Madrasah Tsanawiyah Negeri Cisewu Kabupaten Garut. UIN Sunan Gunung Djati Bandung.

Mulyasa, E. (2004). Manajemen berbasis sekolah: konsep, strategi dan implementasi.

Murniati, A. R. (2008). Manajemen Stratejik: Peran kepala sekolah dalam pemberdayaan. Perdana Publishing. 
Nuraeni, N., \& Ishak, C. (2017). ANALISIS KEPEMIMPINAN KEPALA SEKOLAH DALAM MENINGKATKAN MUTU PENDIDIKAN (STUDI KASUS SMA NEGERI 5 PATAMPUAN). JURNAL SOSIALISASI, 128-132.

Nurhikmahyanti, D. (2013). Keefektifan Pelaksanaan Supervisi Akademik oleh Pengawas dan Kepala Sekolah Menengah Atas Negeri di Kota Yogyakarta. Inspirasi Manajemen Pendidikan, 1(3).

Ratna, R., \& Torro, S. (2019). Impementasi Sekolah Ramah Anak Di SMAN 3 Makassar. Jurnal sosialisasi, 111-116.

Sulastri, I. (2014). Peran Kepemimpinan Kepala Sekolah dalam Mengembangkan Pendidikan Karakter di MIN 09 Petukangan Selatan Jakarta.

Suyanto, B. (2015). Metode Penelitian Sosial: Berbagai Alternatif Pendekatan. Prenada Media.

Wahyudi, D., \& Azizah, H. (2016). Strategi Pembelajaran Menyenangkan dengan Konsep Learning Revolution. ATTARBIYAH, 26, 1-28.

Wiyono, H. (2012). Pendidikan karakter dalam bingkai pembelajaran di sekolah. CIVIS, 2(2/Juli). 